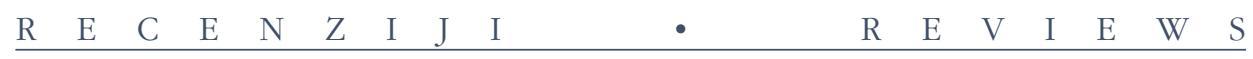

Ankica Petrović

\title{
The Art of Ganga Singing: Cultural Tradition of the Dinaric Area
}

Ankica Petrović. Umjetnost pjevanja gange: kulturna tradicija Dinarske zone [The Art of Ganga Singing: Cultural Tradition of the Dinaric Area]. Livno, Zagreb and Sarajevo: Franjevački muzej i galerija Gorica and Synopsis, 2018. 288 pages + CD-ROM. $23 €$. ISBN: 978-9958-01-060-6 (Synopsis, Sarajevo) 978-953-7968-54-0 (Synopsis, Zagreb) 978-99268173-1-2 (Franjevački muzej i galerija Gorica).

Ganga, currently the most popular traditional vocal genre of the Dinaric area (stretching across Croatia and Bosnia and Herzegovina), is one of the last examples of the archaic style of music making, entirely different from traditional styles and genres based on the heritage of Western European music, such as "klapa" singing. This style of traditional music making serves as an important identification marker of Dinaric communities in Southeastern Europe, both past and present. The author of the proposed book, the Sarajevan ethnomusicologist Ankica Petrović, remains the greatest proponent of the ganga music phenomenon in scholarly circles outside former Yugoslavia.

Petrovićs book is based on her fieldwork research undertaken in the early 1970s, which resulted in her doctoral thesis awarded in 1977, at Queen's University Belfast. This was the first comprehensive study to analyze ganga as a leading genre in the context of other traditional music genres in the Dinaric area - a cultural practice that simultaneously reflects and shapes local, regional, gender and ethnic identifications. The author points out that her choice of topic was a challenge in itself, given that, in Petrović's own words, there was an expectation that she would choose a less "primitive" form of music than ganga, but also that she wanted to confront those very perceptions in the society in which she worked (Petrović 2018, 13). The influence of her mentor, John Blacking, expanded her views on traditional music, and specifically cultural and anthropological approaches to "ganga as culture," along with its overarching structural and performance characteristics - a line of thought that was a novelty in Yugoslav ethnomusicology in the 1970s, and that remains relevant today. Petrović has also embraced a new theoreticalmethodological approach concerned with the meaning and function of music in society, the concepts and practices of "tradition bearers," the dynamics of gender, ethnic and regional identifications, and consideration of music practice in the real contexts of its performance - not on stage but as part of everyday life.

The book comprises five substantial chapters - "Ganga in Time and Society," "Processes of Studying ganga," "Transcriptions of Musical Examples," "Music Style Analysis" and "Aesthetic Evaluation of ganga" - framed by a preface, introduction and conclusion. The book also includes a CD with thirty-five fieldwork recordings of ganga, 
which according to Petrović are of poor quality due to multiple dubbing and storage on various inadequate media, circumstances beyond her control.

Petrović's starting premise is that the basic characteristics of the structure of the traditional song and dance/musical style cannot be analyzed without addressing the social and cultural relations in which they are created. Ahead of its time yet still relevant today, Petrović's pioneering approach places ganga alongside contemporary genres as an important factor in the formation of local musical cultures, and her cultural-anthropological approach to ethnomusicological research remains current today. What is lacking in her study, however, is a better insight into the contemporary scholarly context, given that there have been numerous changes in the understanding of the concept of ganga, its musical style and its new roles and functions compared to the 1970s, when the author carried out her research. In this sense the book would benefit from engaging with the work by other, more recent scholars in the field. ${ }^{1}$

Describing ganga, Petrović observes that it is a musical phenomenon that invokes either completely agreeable or utterly unpleasant reactions: for urban individuals ganga is crude and unbalanced, closer to shouting or crying. She argues that amongst the urban population there is a belief that this music is "primitive" and should be replaced by other more acceptable musical forms, such as bećarac. Yet despite such opinions, ganga remains an authentic and prominent musical expression that not only continues to be a part of regional musical vocabulary, but has also made inroads into the urban environments, which reinforces the social component of ganga as musical communication among members of the same community, and specifically between rural and urban layers of society. Ganga functions as leisure-time musical activity, regarded as the most beautiful compared to other songs such as bećarac, sevdalinke and "singing over the bass" (pjevanje na bas), especially according to the younger and middle-aged generation of ganga performers. Petrović's informants claim that performing ganga requires great vocal skills, comparable with other important skills, such as dancing and playing.

The fieldwork for this book resulted in the substantial collecting of audio data. The recorded gangas were transcribed in Western European notation, though the recording emphasizes narrow intervals and the untempered system (microtonality) as a fundamental feature of this music genre. In contrast to the usual method of song collecting and transcription common at that time, Petrović also studied how the songs are taught, the social background of musical performance, the use and function of ganga and other ancient singing styles in general. She was also interested in processes that modify and adapt ganga in the socio-political and specific cultural environments, recognizing different ganga styles - a process through which she highlighted the qualities of local knowledge transfer, as well as the valuable "older" musical elements of genres

1 Anne-Florence Borneuf, "Plaisir partagé et frissons individuels: Chanter et écouter les chants ganga (Croatie / Bosnie-Herzégovine)," Cahiers d'Ethnomusicologie 23 (2010), 73-84 (accessed March 14, 2018, http://ethnomusicologie.revues.org/971); Dieter Christensen, "Agents of change: Musical practices in a village of the Hercegovina, 1957-1974," in Velika Stojkova, ed., Proceedings: First Symposium of the ICTM Study Group for Music and Dance in Southeastern Europe (Skopje: COKOM, 2008), 89-101; Joško Ćaleta, "Trends and Processes in the Music Culture of the Dalmatian Hinterland", Music \& Anthropology: Journal of Musical Anthropology of the Mediterranean 6 (2001) accessed March 14, 2018, https://www.umbc.edu/MA/index/number6/caleta/jos_0.htm, and "Ganga party, Let iznad gangina gnizda iliti multimedijalno predstavljanje (ne)odbačene tradicije", Kazalište 12/39-40 (2009), 134-43. 
that were precursors to ganga. On the other hand, the author's analytical focus is on the musical-stylistic features of ganga, and her monograph is an exemplary ethnomusicological study in the sense that it blends musical, cultural and anthropological approaches, namely the consideration of musical and cultural aspects of the ganga. The transcribed corpus of songs was divided according to a regional-geographic basis, preserved by the inhabitants according to special stylistic characteristics of the given gangas. The subcultural textual and musical characteristics are not conceived within established musical norms, but defined by the performers and the audience. Petrović uses the terminology of the local communities that she studies, a musical world in which "music" (as a concept) is described though singing, playing, dancing and various interactive situations during singing, in which musical actors communicate through specific actions, such as "goniti", "jecati", "spuštati", "dizati", etc. In terms of terminology, Petrović avoids the word music, which defines the art of organized sound in the Western world, and her extended terminological vocabulary further extends the concept of ganga musical experience.

Pronounced differences in singing, which emerge between different ethnic groups in the region, are seen as variants that have the same origins, although comprising elements pertaining to different ethnic groups. Her democratic attitude towards ganga, as the equal musical creation of all the people who live in this region, as well as her emphasis on the war-time nationalistic aspect of singing ganga by Croats during the Homeland War, have contributed to the negative reception of Petrovićs research on ganga. In this sense, history is repeating itself: a similar fate followed the earlier ganga scholar Branko Marić, a Catholic priest who emigrated from Herzegovina after the Second World War, and whose work was never acknowledged in Socialist Yugoslavia due to his political unsuitability.

In summary, Petrović recognises some of the common characteristics that mark the conspicuous ganga style, namely the structure of ganga patterns and the principles of the organization. Given that this music is an oral tradition, an unwritten cultural activity, it means that a great concentration is needed in performance, which at the same time is proof that it is learned from others in the same socio-cultural environment. The fact that Petrović's analysis was largely based on insights gained during her fieldwork research during the 1970s and 1980s actually adds value to this study, testifying to a past that would otherwise be undocumented. In that sense, this book can serve as an example to younger generations of ethnomusicologists who, as far as the Croatian environment is concerned today, largely ignore the valuable earlier approaches of song collecting, transcription and analysis, as was common practice before the 1990s. This example could, in turn, serve to introduce and promote insights from the field of cultural anthropology: as Petrović's monograph was compiled forty years ago, with a thesis that opposed the "primitive" association of the ganga and Dinaric communities, it similarly contests modern-day views about drawing ethnic and national boundaries through ganga. All these factors attest to the importance of both the scientific and wider social contribution of this work. The main weakness of this study, however, is the lack of information about changing musical and stylistic characteristics, as well as the absence of reference to the contemporary understanding of ganga, especially pertinent for new generations of scholars. 
To conclude, just as Petrović forty years ago used her dissertation to contest the notion of primitiveness associated with ganga and the communities who upheld this heritage, with her book today she counters contemporary attempts to draw ethnic and national boundaries through ganga. As such, this work offers not only an important scientific but a wider socio-cultural contribution. In addition, and perhaps more importantly, just as this work introduced and broadened the field of cultural anthropology forty years ago, today it similarly reminds younger scholars about the necessity of grounding their research in musical enquiry. I therefore recommend this book to music students, especially those of ethnomusicology, who will find a foundational study about music-making specific to ganga, as well as a wider readership who are connected to the Dinaric region famous for ganga.

Joško Ćaleta Institute of Ethnology and Folklore Research, Zagreb 